\title{
Working with the Enemy: Axis Prisoners of War in Iowa during World War II
}

\author{
CHAD W. TIMM
}

IN A RELATIVELY UNKNOWN and underpublicized military operation, German, Italian, and Japanese soldiers came to the United States during the Second World War. Without the help of these Axis prisoners of war (POWs), American farmers and manufacturers might not have met the growing wartime demand for food and supplies. The initial widespread capture of German and Italian soldiers came as a result of the Allies' successful 1942 North Africa campaign against Adolf Hitler's Afrika Korps. ${ }^{1}$ The British, not able to accommodate the increasing number of POWs on their soil, called upon the United States to aid in POW internment.

Thus, in late 1942 and early 1943 the U.S. government constructed dozens of camps in isolated areas of the South and Southwest. Between April and August 1943, prisoners of war totals in the United States grew from less than 5,000 to more than 130,000. As the number of Axis POWs in the United States increased, the federal government established camps beyond the South and Southwest. The U.S. Army supervised the construction and operation of these facilities. By the end of World War II, the United States interned nearly 400,000 Axis prisoners of war in more than 400 camps across the country.

1. The eventual Allied victories in the Pacific Theater in 1944 led to the first significant captures of Japanese soldiers. See Arnold Krammer, "Japanese Prisoners of War in America," Pacific Historical Review 52 (1983), 67-91.

THE ANNALS OF IOWA 70 (Summer 2011). (C) The State Historical Society of Iowa, 2011. 
Two of these POW camps were in Iowa: one near the Kossuth County town of Algona and the other near the Page County town of Clarinda. These POW camps placed the citizens of the nearby communities in an uneasy position. Faced with an acute shortage of laborers, Iowans had to turn to the enemy for help. Enemy POWs eventually became an integral component of the American domestic war effort. ${ }^{2}$

By mid-1943, with increasing numbers of American men serving overseas, some areas of the United States experienced severe civilian labor shortages. According to historian Stephanie Carpenter, "Between April 1940 and July 1942 more than 2 million men left the farm, and by the end of the war, the agricultural population had decreased by six million. As a result, the nation's farmers called for federal measures to provide labor and assistance for the production of their crops." In 1943 the federal government responded by creating the Women's Land Army to help address the issue of farm labor, but midwestern "farmers discouraged the use of women to assist in the region's fields, citing their inability to operate heavy farm equipment." ${ }^{3}$

Many American farmers turned instead to enemy prisoners of war. Sanctioned by the 1929 Geneva Prisoner of War Convention, prisoners of specified ranks also ameliorated labor shortages in lumbering, mining, construction, food processing, and other non-governmental work not directly related to the war effort. ${ }^{4}$ As stories of successful POW employment spread throughout the United States, smaller work camps were constructed in locations where workers were most needed.

Iowans, who farmed some of the richest, most fertile soil in the world, struggled to meet the War Food Administration's increasing agricultural goals as the draft deprived the state of vital farm laborers. As Lisa Ossian chronicles, "By 1943, Iowa employed 70,000 fewer farm workers than before the war, and

2. George Lewis and John Mewha, History of Prisoner of War Utilization by the United States Army, 1776-1945 (Washington, DC, 1955), 90; Terry Paul Wilson, "The Afrika Korps in Oklahoma: Fort Reno's Prisoner of War Compound," Chronicles of Oklahoma 52 (1974), 362.

3. Stephanie Carpenter, "At the Agricultural Front: The Women's Land Army during World War II" (Ph.D. diss., Iowa State University, 1997), 87, 297.

4. Lewis and Mewha, History of Prisoner of War Utilization, 90. 
its farm machinery was aging, becoming more and more difficult to repair. The situation grew increasingly desperate. Farmers at first turned to townspeople, foreign labor, and teenagers, as well as their own families." Ossian depicts Iowa farmers, who dedicated themselves to the Food for Freedom program, as "soldiers of the soil." ${ }^{5}$ Ironically, some of those "soldiers of the soil" were actually enemy prisoners of war.

Amid reports of Iowans being captured, wounded, and killed in the European and Pacific theaters, Iowans at home chose to accept the help of POW labor in order to meet their agricultural goals and aid the war effort. For many community members, acceptance did not mean an unquestioning fondness or affection for the prisoners, but rather an understanding that acceptance meant helping the United States win the war. For some Iowans, however, acceptance meant realizing the ambiguity of the term enemy as they developed friendships with POWs that would sometimes last for decades after the war's end. Although not always economically profitable, POW labor allowed local canneries, hemp plants, nurseries, and area farmers to meet their wartime production goals. Thus, the story of employing enemy prisoners in Iowa during World War II is a story of coming to grips with reality: POW labor enabled Iowa farmers to meet wartime goals, see the true face of the enemy, and learn that even amid the terror and destruction of war, humanity prevails.

BY THE END OF 1942, Iowa began to suffer from a labor shortage as many of the state's workers had joined the armed services. In February 1942, for example, Clarinda's local National Guard unit, an anti-tank unit of the 168th Infantry Regiment, received its mobilization orders, depleting Page County of 2,000 potential laborers. ${ }^{6}$ With thousands of hungry soldiers being shipped overseas daily, key agricultural states like Iowa increased food production in order to feed them.

In March 1942 Algona's local newspaper encouraged Kossuth County farmers to raise more sugar beets in order to keep the state's two sugar beet plants at full operation. Fear of an in-

5. Lisa Ossian, The Home Fronts of Iowa, 1939-1945 (Columbia, MO, 2009), 29.

6. Clarinda Herald Journal, 6/25/1942, 4/23/1942, 11/19/1942. 
adequate labor supply caused local farmers to hesitate. They had also been asked to boost hog and egg production and to increase the acreage devoted to soybean and flax crops. In north central Iowa, U.S. Employment Service representative John Gish noted the probable farm labor emergency for the coming season and called on everyone to help. ${ }^{7}$

Concern among farmers continued to grow. By August 1942, the local newspaper noted that the 4,245 farm families in Kossuth County found the job of increasing production difficult due to a dwindling pool of labor, higher farm wages, and the limited availability of machinery and supplies. Conscription and high wages paid by government industries drained the farms of their manpower. The local newspaper remarked, "It begins to look like the army boys may have to fight on empty stomachs." ${ }^{8}$

In the fall of 1943, with the harvest season ahead, the farm labor problem in Page County became acute. The Farm Extension Office reported that labor demands exceeded the supply of available workers. In September 1943, 76 percent of Page County farmers reported that they would need help at corn-shucking time, although the largest demand was for year-round help. Without outside labor, Page County farmers turned to each other for harvest help. One such dairy farmer near Clarinda called on five farmers whose ages ranged from 43 to 83 to help shuck 14 acres of corn. ${ }^{9}$ A few farmers and farm organizations had harvest demands that neighbors could not accommodate, however, and were forced to turn to an unlikely source for help.

In 1943, the DeKalb Agricultural Association of Shenandoah, producers of hybrid seed corn, anticipating an inadequate supply of laborers for summer detasseling work, contacted county Extension agents in Page and Fremont counties, hoping to locate about 500 detasselers. The prospect of finding so many summer workers to detassel looked bleak. The Page County Extension Office certified the need for an alternate labor source. ${ }^{10}$

7. Algona Upper Des Moines, 3/24/1942, 4/14/1942.

8. Ibid., 7/28/1942, 10/13/1942.

9. Clarinda Herald Journal, 9/30/1943, 10/25/1943, 11/25/1943.

10. Page County Extension Office, Annual Narrative Reports, 1943, 7. This and all of the annual narrative reports compiled by county Extension agents cited hereafter are found in Special Collections, Iowa State University Library, Ames. 
Given that POW labor from camps as close as Nebraska and Missouri had been used extensively for nearly a year, seeking out POW labor made sense. Thus, DeKalb contracted with the U.S. Army to establish a temporary side camp, under the administration of a larger main camp in Missouri, to house POWs at the old Civilian Conservation Corps (CCC) camp near Shenandoah. During July and August 1943, Camp Weingarten, Missouri, sent approximately 300 Italian POWs to Shenandoah. ${ }^{11}$ Those POWs handled most of DeKalb's detasseling work, which freed local laborers for employment by other hybrid seed producers in the area. ${ }^{12}$

In 1943 Italian POWs were also employed on the Adams Ranch near Odebolt in Sac County. Comprising 6,400 acres, the Adams Ranch, the largest farm in the state, had 2,800 acres of corn, 270 acres of flax, 685 acres of oats, 1,065 acres in tame hay, 1,040 acres of red clover, and 10 acres of potatoes, with the remaining acres in pasture. After several attempts to secure labor from a local conscientious objector camp had failed, the Italian POWs were brought in to shock and thresh 2,100 acres of grain that otherwise would have rotted in the fields. Another 200 Italian prisoners of war worked for two months in a hemp plant near Eldora, Iowa, in late 1943. ${ }^{13}$ Although these POWs imported from neighboring states alleviated a few specific labor problems, the farm labor emergency in Iowa was just beginning.

11. The status of Italian POWs changed in September 1943, when Italy declared war on Germany, its former ally, and the United States found itself in possession of 50,000 Italian prisoners of war. To remedy this situation, Italian POWs who agreed to pledge allegiance to the Allies were placed in Italian Service Units, where they were given more freedom and allowed to perform jobs that were prohibited to German and Japanese prisoners. See Louis Keefer, "Enemies Turned Allies: Italian POWs in Ohio," Timeline 50 (March-April 1993), 47-55.

12. Page County Extension Office, Annual Narrative Reports, 1943, 7; Clarinda Herald Journal, 8/9/1943.

13. Page County Extension Office, Annual Narrative Reports, 1943, 3-7; Sac County Extension Office, Annual Narrative Reports, 1943, 9; Algona Upper Des Moines, 7/29/1943; Eldora Ledger Herald, 12/6/1945. Hemp plants in Iowa processed hemp to be made into rope. Rope shortages for merchants and the U.S. Navy had become an acute problem. Before Pearl Harbor, 98 percent of America's hemp was imported from the Philippines, which had come under Japanese control. Algona Upper Des Moines, 11/24/1942, 1/7/1943. 


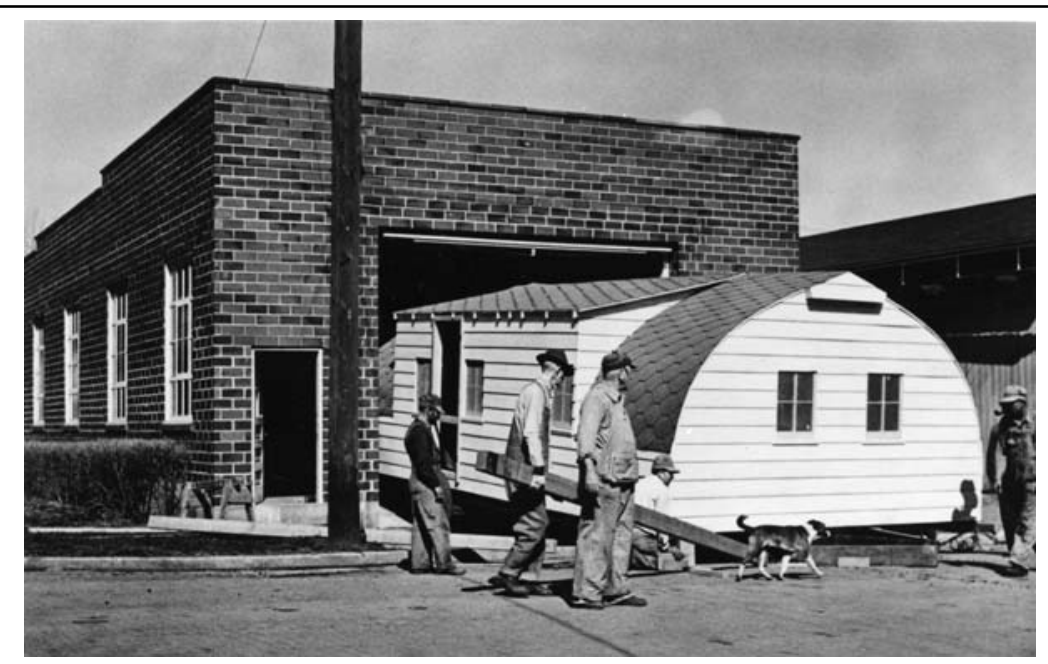

Workers prepare buildings at Camp Clarinda. Photo from State Historical Society of Iowa, Iowa City (SHSI).

CAMPS FOR AXIS PRISONERS OF WAR came to Iowa as a result of the efforts of local Chamber of Commerce officials, such as Hans Morgan of Clarinda and C. A. Phillips of Algona, who believed that the construction of a camp would stimulate the local economy and possibly provide a source for agricultural labor. ${ }^{14}$ On July 22, 1943, government representatives arrived in Algona to inspect potential sites for a prisoner-of-war camp; within a month the Seventh Service Command, responsible for POW operations in the Midwest, authorized the construction of such a camp. Citizens of Clarinda, Iowa, received notice a few days later that a similar camp would be built near their town. Senator Guy M. Gillette announced that the Army Corps of Engineers, operating out of Omaha, Nebraska, anticipated completing the camps within two to six months. ${ }^{15}$ Sud-

14. Chamber of Commerce officials probably lobbied Iowa Senator Guy M. Gillette, who chaired the relevant subcommittee of the Senate Agricultural Committee. Such lobbying cannot be documented but is what generally took place nationally. See Joseph T. Butler Jr., "Prisoner of War Labor in the Sugar Cane Fields of Lafourche Parish, Louisiana: 1943-1944," Louisiana History 14 (1973), 283-96.

15. Algona Upper Des Moines, 7/22/1943, 8/19/1943; Clarinda Herald Journal, 8/23/1943. 


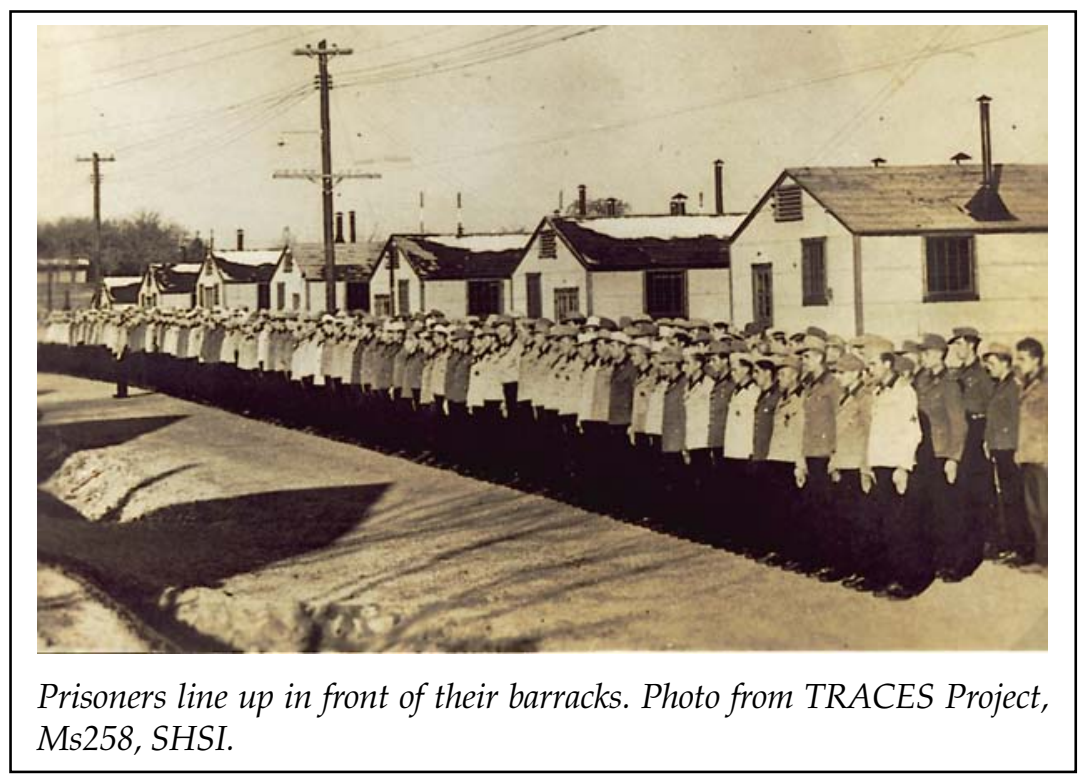

denly, a war occurring thousands of miles across the world was coming directly into the heartland.

The camps at Algona and Clarinda were identical, as the Army Corps of Engineers required new camps to be built in accordance with a standard design plan. Once completed, each had the potential to nearly double the local populations. Architectural designs permitted 3,000 POWs and 500 American soldiers to live in approximately 186 buildings at each camp. The buildings were set on concrete foundations and composed of wood frames covered by composition siding and roofing, with interior walls made of plasterboard. Each camp consisted of four compounds, three for prisoners and the fourth for the American garrison. Barbed-wire fence with towers manned by machine-gunners at each corner separated the three prisoner compounds with 20 frame barracks each housing 50 men. Once completed, both camps included a post theater, church, fire station, icehouse, machine shop, barn, hospital, electric distribution system, and water and sewage facilities. ${ }^{16}$

16. Kossuth County Advance, 9/21/1943; Algona Upper Des Moines, 1/18/1944; Des Moines Register, 1/26/1944. 
With little warning, the first POWs arrived by train at Camp Algona and Camp Clarinda in late January 1944. The first Germans to arrive were members of Hitler's vaunted Afrika Korps. To a reporter from the Des Moines Register, they appeared goodlooking, well fed, happy, friendly, energetic, and typically between 21 and 25 years old. ${ }^{17}$

The establishment of POW camps in Iowa had occurred quickly. By October 1944 each camp housed nearly 2,500 prisoners. ${ }^{18}$ POWs had to learn quickly to reorder their lives, a process that depended heavily on their daily routines in the camps.

AT BOTH CAMP ALGONA AND CAMP CLARINDA,
treatment of POWs adhered strictly to the Geneva Prisoner
of War Convention. ${ }^{19}$ The United States had signed the treaty in 1929, and the Senate ratified it in 1932. As a signatory, the United States undertook the responsibility to treat POWs according to the convention's bylaws. Once POWs arrived at their assigned camp, they were fingerprinted, photographed, and checked for typhus-carrying lice - a process that could take from a few days to several weeks, depending on the number of prisoners arriving at any given time. Once processing was complete, prisoners settled into typical daily routines. ${ }^{20}$

POW camps across the country followed similar daily schedules. Prisoners awoke to the sound of reveille at 5:30 a.m., and they had their beds made and breakfast eaten by 6:30 a.m. Then they marched from the mess hall back to their barracks, where they showered and cleaned up in preparation for the day's work projects. The Geneva Convention required all prisoners below the rank of sergeant to work either inside or outside the camp when ordered to do so, while non-commissioned officers and officers could request work. Thus, in January 1943

17. Des Moines Register, $1 / 22 / 1944$.

18. Des Moines Register, 3/30/1944; Office of the Provost Marshal General, "Weekly Report on Prisoners of War, as of 23 October 1944," World War Two file, State Historical Society of Iowa, Des Moines.

19. For a detailed description of the Geneva Convention, see Lewis and Mewha, History of Prisoner of War Utilization, 66.

20. Clarinda Herald Journal, 9/21/1944; Des Moines Register, 10/1/1945, 10/2/ 1945; Arnold Krammer, Nazi Prisoners of War in America (New York, 1979), 46. 
the government established a national work program, which divided POW labor into two classes. Class I included labor required to maintain prison camps; Class II encompassed all other types of labor not directly connected with military operations. ${ }^{21}$ POW labor projects took place outside as well as inside the camp. POWs contracted by civilians for labor were loaded onto trucks by 7:30 a.m. and taken to the work site. Lunch was provided to the prisoners at noon; after three more hours of work, the POWs were loaded on the trucks for transfer back to camp. Once they returned to camp, they ate dinner between 6:00 p.m. and 7:00 p.m., after which they had the remainder of the evening as free time. ${ }^{22}$

Routine and monotony could challenge the camp's safe and secure environment. Recreational activities helped to pass the time and combat boredom. Sports were generally the most important pastime. Other activities included choral groups and theater. Prisoners also became involved in religious activities, as most of the German prisoners were Roman Catholic or Lutheran. Arts and crafts also played a key role in the daily life of German prisoners and gave the POWs a chance to express themselves. At Camp Algona, for example, German POW Edward Kaib and five of his cohorts created a notable example of prisoner woodworking. In November 1945 the Christmas season brought the unveiling of a POW-made nativity scene at the camp. Over the course of the year the prisoners carved and built the nativity scene with more than 60 half-life-size wooden figures. It remains on display at the Kossuth County Fairgrounds.

Prisoners could also purchase items from the Post Exchange, using canteen coupons they earned. In 1944, based roughly on the $\$ 21$ per month earned by a private in the U.S. Army, POWs

21. Lewis and Mewha, History of Prisoner of War Utilization, 76-78, 362; Edward J. Pluth, "Prisoner of War Employment in Minnesota during World War II," Minnesota History 44 (1975), 302; Arthur Lobdell, "Report from A. T. Lobdell to Governor Dwight Griswold, 9 January 1947," Algona POW Camp vertical file, Algona Public Library, Algona.

22. Krammer, Nazi Prisoners of War in America, 48; Major General Arthur L. Lerch, "The Army Reports on Prisoners of War," American Mercury, May 1945, 541-42.

23. Algona Upper Des Moines, 11/29/1945; George H. Lobdell, "A Tale of Two Christmases at the Algona Prisoner-of-War Camp," Palimpsest 73 (1992), 170-88, to which are appended color photographs by Chuck Greiner of the nativity scene. 


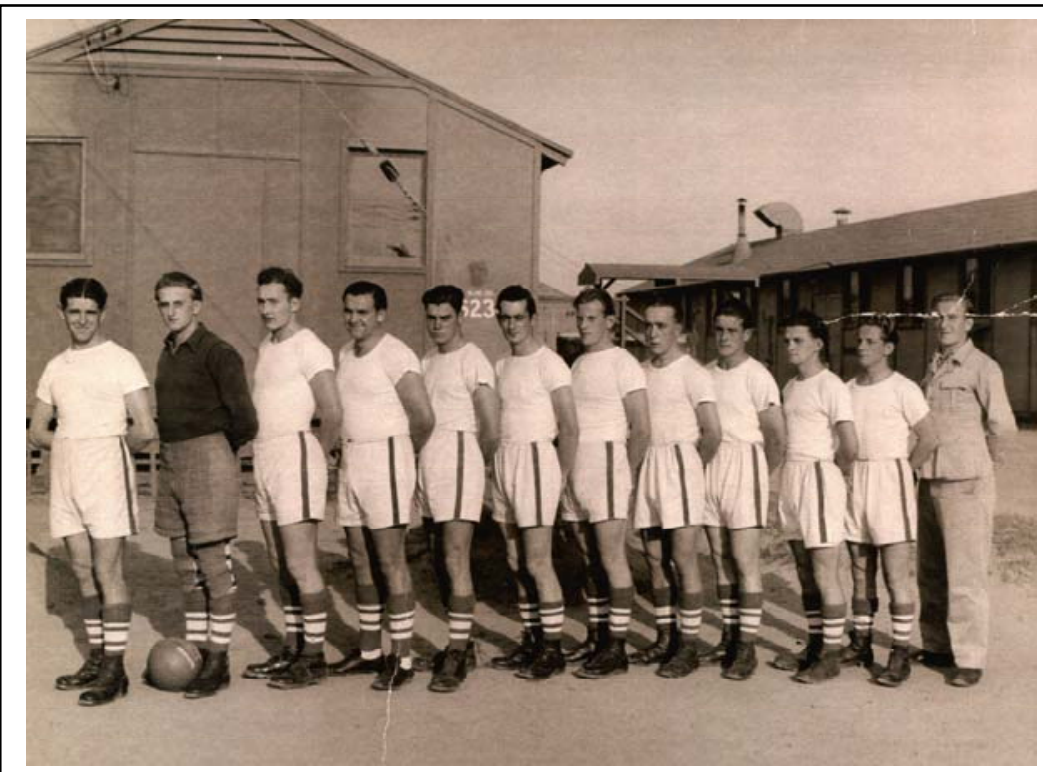

Recreational activities, especially sports, were an important means of combating boredom in the POW camps, thus contributing to a safe and secure environment. Photo from TRACES Project, Ms258, SHSI.

were paid 80 cents per day for work outside of the camp; those who worked within the camp made 10 cents per day. Prisoners had the choice of placing the money earned in a trust fund account to be redeemed upon repatriation or receiving wages in the form of canteen coupons redeemable at the PX. One Camp Algona officer stated, “They aren't interested in saving the money they earn. It doesn't mean anything to them as prisoners. They like real things that they can see and feel and use." ${ }^{24}$

Items available at the prisoner canteens included money belts, razors, toilet articles, combs, brushes, tobacco, candy, soft drinks, classic literature, and radios. Name-brand cigarette makers discouraged the selling of their cigarettes to POWs, so the prisoners resorted to rolling their own. Prisoner canteens also provided beer for the POWs, who could buy two pints of beer per day after they returned to the compound for the night. This beer contained 3.2 percent alcohol, the standard for Iowa. 
The POWs considered this beer "too soft" because they were accustomed to 8-14 percent alcohol in Germany. This did not discourage the drinking of beer, but German POWs often resorted to the fermentation of raisins, grapes, peaches, and other fruit in homemade stills. ${ }^{25}$

The army used the profits from camp canteens to purchase inventory, to improve the prisoners' quarters, or for entertainment, such as games, athletic equipment, or wood for woodworking and musical instruments. The canteen at Camp Algona, for example, raised enough money to purchase a second-hand piano and enough instruments for a 15-piece orchestra. ${ }^{26}$

The U.S. Army hoped that treating German POWs fairly would inspire more Germans to surrender and would avoid giving the Germans an excuse to mistreat American POWs being held in Europe. Captain Clyde Herring, a former POW himself, reported that German-speaking American soldiers overheard German civilians talking about the fair treatment their relatives were receiving in the United States. German soldiers, hearing of the treatment their comrades received in American as opposed to Soviet camps, were more likely to surrender to American troops. ${ }^{27}$ News regarding German surrenders in Europe had a tremendous effect on the citizens of Clarinda and their acceptance of its German inhabitants, as a number of Page County soldiers had become occupants of European prison camps.

Despite the startling speed with which enemy soldiers appeared in Iowa, camp officials in Iowa deliberately and successfully created a relationship between the prisoners and their captors that fostered a safe and productive environment. The host communities made a similar effort, thereby establishing a stable framework for the launch of a successful POW labor program.

25. Des Moines Register, 3/30/1944, 4/23/1944, 10/2/1944, 10/8/1944; Clarinda Herald Journal, 3/30/1944; Corinne and Wilbur Goecker, interview with author, Clarinda, Iowa, 3/21/2000. Corinne (Noland) Goecker was the private secretary for Camp Clarinda's commanders, Lobdell and Ball, prior to her marriage in late 1944.

26. Algona Upper Des Moines, 10/10/1944; Kossuth County Advance, 11/23/1944. 27. Wilson, "The Afrika Korps in Oklahoma," 367; Shenandoah Evening Sentinel, 6/26/1945. 
THE FUTURE of Iowa's agricultural contribution to the war effort depended on the availability and acquisition of a reliable local supply of labor. Large farm operations and businesses like DeKalb and the Adams Ranch required large numbers of workers. These large operations had experience finding alternative supplies of farm workers, including immigrants from Mexico. Farmers with average-size operations, however, struggled to find alternatives. Although enemy POWs appeared to be good candidates to relieve the farm labor shortage, bureaucratic guidelines initially made their use difficult.

In February 1944, soon after the opening of the Algona and Clarinda encampments, camp officials made announcements regarding prisoner-of-war employment. Meanwhile, the War Manpower Commission declared that POWs could be employed only through the local U.S. Employment Service Office. Therefore, employers had to place a legitimate order for the workers needed with their local employment office to ensure that local labor was not available. Farmers' requests for agricultural laborers were then passed on to the local Extension office, or in some cases to local emergency labor associations. If either office determined that local labor could not fulfill the labor need, a certificate of need for POW employment was issued. ${ }^{28}$

Employing POW workers required that no local labor existed, and payment needed to be comparable to that of the going rate for local labor, generally 50 to 60 cents per hour for POWs employed in agricultural labor and about 8 cents more for nursery work. The farmers paid the federal government for the use of their labor, and the government in turn paid the prisoners. In short, farmers had to contact the county Extension office, which contacted the War Manpower Commission, which in turn contacted the camp commander, who then approved the labor request. Farmers eagerly anticipating shipments of German POWs quickly became discouraged. ${ }^{29}$

The complicated procurement procedures forced the War Department to institute an easier method to obtain POW labor.

28. Algona Upper Des Moines, 2/22/1944.

29. Ibid. 
In March 1944 the War Department allowed the Agricultural Extension Service to act as the official arbiter between farmers and POW camp authorities. By purchasing "man-days" ahead of time, the Extension Service established a reservoir of labor available to local farmers upon demand. When in need of agricultural labor, the farmer now only needed to apply to the Agricultural Emergency Labor Association, sign regulation agreements, travel to the camp to pick up the POWs, and pay the government later. As farmers and camp officials alike became more familiar with the process, farmers would call the camp a day in advance announcing their labor needs for the following day. To quell objections from local labor leaders, regulations required documentation (such as an advertisement placed in a local paper requesting help) that no local labor was available. ${ }^{30}$

During the 1944 season, POW labor performed many farm tasks throughout Iowa and proved to be invaluable, because the War Food Administration had set high food production goals for that year. ${ }^{31}$ Kossuth County farmers used German POWs for general farm labor, such as tractor driving, guiding teams of horses, hauling, silo filling, harvesting seed corn, and working in potato fields, in addition to nursery work. Near Algona, farmers used POW labor for haying, harvesting, corn detasseling, and silo filling. In August 1944, 174 German POWs were employed to pull weeds near Humboldt. German POWs generally worked for farmers in groups of five to ten, while the Sherman Nursery near Charles City employed 50 German prisoners daily. ${ }^{32}$

Contract work in Page County included clearing roots and stumps from hedgerows, tile ditch digging, laying out of tile ditch surveys, hauling manure, fence building, and tree plant-

30. Wilson, "The Afrika Korps in Oklahoma" 363-64; Krammer, Nazi Prisoners of War in America, 89; Clarinda Herald Journal, 2/2/1944, 3/13/1944, 3/6/1944, 3/10/1944, 4/20/1944, 6/1/1944, 7/3/1944; Page County Extension Office, Annual Narrative Reports, 1944, 7.

31. The Kossuth County Extension Office set goals of 239,000 acres of corn, 78,000 acres of soybeans, 11,000 acres of flax, and 120,300 acres of oats. Algona Upper Des Moines, 12/9/1943.

32. Algona Upper Des Moines, 9/12/1944, 9/24/1944; Kossuth County Advance, 11/2/1944; Provost Marshal General's Inspection Report, G, 9/7-9/1944, copies provided to author by George Lobdell, Lt. Col. Arthur Lobdell's nephew; Humboldt County Extension Office, Annual Narrative Reports, 1944, 12. 
ing. Prisoners also labored in hay harvest, corn detasseling, and other miscellaneous farm jobs. In May 1944 Fremont County growers, just west of Page County, used POWs to help harvest more than 400 acres of asparagus. Fremont County farmers also used POW labor to assist in pea and sweet corn harvests, in addition to corn detasseling. Harley Walker, the Fremont County Extension Service agent, said that these men were "mostly young, sturdy fellows who worked best if supervised by one foreman from their group." ${ }^{33}$

To supply POW labor to locations that most needed the workers sometimes required the establishment of temporary branch camps. In February 1944 the War Department adopted a "calculated risk" policy that permitted the movement of POWs from large base camps to smaller, less secure branch camps. ${ }^{34}$ Branch camps under Camp Clarinda's administration operated in Iowa, Kansas, and Nebraska during 1944. In Hannibal, Missouri, 200 prisoners sorted used army boots for distribution to liberated countries; 125 dehydrated alfalfa in Liberty, Missouri; 200 constructed a veterans hospital in Wadsworth, Kansas; 20 canned corn in Wapello, Iowa; and 80 did construction work in Audubon, Iowa. Branch or satellite camps also functioned effectively in Orrick and Independence, Missouri; Clinton, Iowa; and West Point, Nebraska. ${ }^{35}$

Throughout 1944 and 1945 Camp Algona administered 34 branch camps in Minnesota, North and South Dakota, and Iowa. ${ }^{36}$ The number of branch camps operating at any one time in Iowa ranged from 2 in September 1944 to 11 by mid-1945. Although branch camps generally employed German prisoners in rela-

33. Clarinda Herald Journal, 5/4/1944, 7/3/1944; Page County Extension Office, Annual Narrative Reports, 1944, 2; Fremont County Extension Office, Annual Narrative Reports, 1944, 15 (quote).

34. The term "calculated risk" refers to a change in policy that was the result of less concern about escape attempts and a desire to expedite the work program. See Merrill R. Pritchett and William Shea, "Afrika Korps in Arkansas, 1943-1946," Arkansas Historical Quarterly 37 (1978), 32.

35. Des Moines Register, 10/8/1944; Clarinda Herald Journal, 6/19/1944, 11/13/ 1944.

36. Post Engineer's Office, Prisoner of War Camp, Algona, Iowa, "Branch Camps: Operations and Activities Map," November 1945. Map provided to author by George Lobdell, Lt. Col. Arthur Lobdell's nephew. 
tively small numbers, ranging from 49 to more than 200, establishing branch camps allowed valuable labor to be used where it was needed the most.

Despite some difficulties, the Iowa POW labor program in 1944 was a success. Early in the season, procurement proved difficult because of the complicated procedures, and, because there were few operating branch camps, only farmers within a radius of 15 to 30 miles of the camp could benefit from the labor. By late season, however, procurement procedures had been simplified and more than a dozen branch camps created. As a result, in the months of June, July, and August 1944, 963 farm labor placements were made in Page County, accounting for 12,491 man-days of prisoner labor used by 60 farmer-employers. In Kossuth County, more than 100 farmers used German POWs during the 1944 season. The local numbers would gradually increase with the creation of additional branch camps and familiarity with the procurement process.

Because the employment of German prisoners during the 1944 season proved successful, POW labor was used again when needed during the 1945 season. In January 1945, 900 acres of hemp remained unharvested near Eldora. The local hemp plant contracted POW labor through the spring, and German POWs could be seen loading and unloading hemp in knee-deep snow. In March the Algona Upper Des Moines reported that farmers had not met the Agricultural Adjustment Administration's flax goal for Kossuth County. In some areas the lack of labor had led to serious delays in the harvest the previous year, so flax producers were hesitant to plant the necessary acreage in the spring. Farmers employed POW labor to help ease this predicament. ${ }^{37}$

The spring of 1945 witnessed POW workers hauling manure, tiling, and making hay. Kossuth County's Farm Bureau again entered into a contract as employer in order to establish a labor pool for local farmers, eliminating some of the bureaucratic hurdles in the procurement process. Kossuth County farmers also continued to use POW labor in the sugar beet harvest during the 1945 season. L. A. Nitz, for example, drove to Algona each morning to retrieve 26 German POWs to assist

37. Eldora Ledger Herald, 1/25/1945; Algona Upper Des Moines, 3/22/1945. 


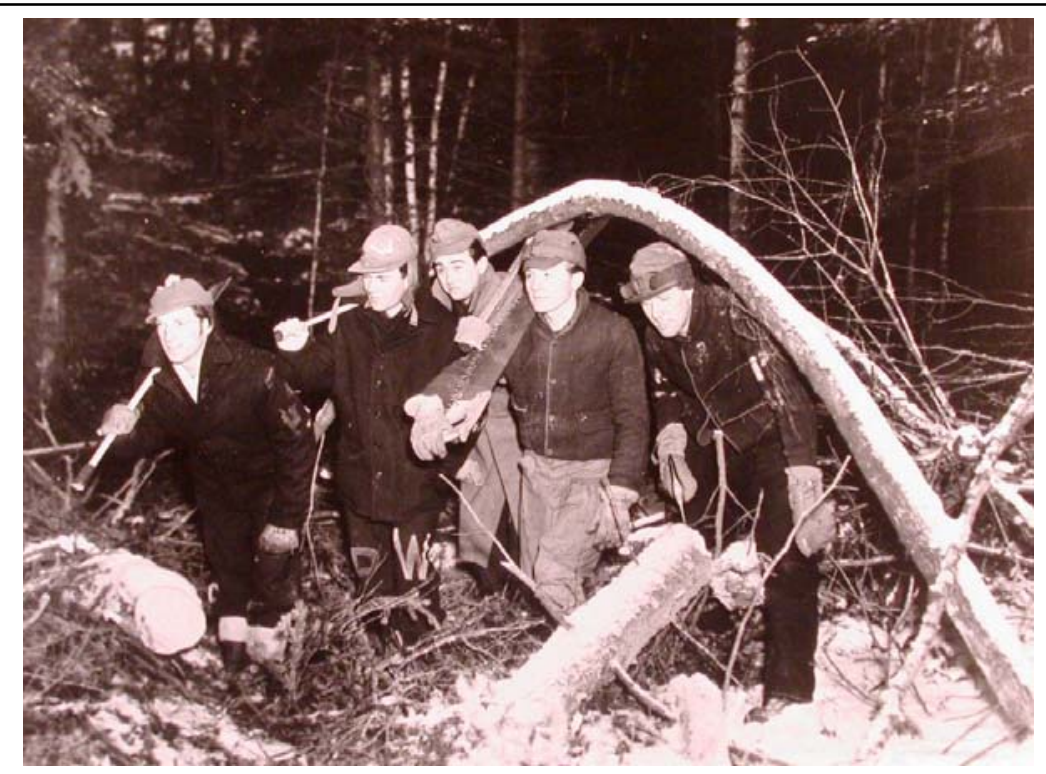

POWs at branch camps worked at a variety of tasks, including logging and brush clearing. Photo from TRACES Project, Ms258, SHSI.

with his sugar beet crop. In September 1945 the Fort Dodge Messenger reported that German POWs from Camp Algona were engaged in clearing trees and brush from roadsides where roadwork was being conducted. ${ }^{38}$ The more efficient procurement process also encouraged the establishment of additional branch camps throughout Iowa in 1945 to alleviate labor shortages. ${ }^{39}$

Given the high rate of turnover between camps, the number of prisoners at Camp Algona varied. In 28 months, Camp Algona and its branch camps housed 10,000 Germans, averaging 3,261 per month. During that time, German POWs were employed in logging (15 percent), agriculture (20 percent), factory work (35 percent), and government work at Sioux Falls Air Base, Missouri River, and other camps (30 percent). From June 1944 to February 1945, main and branch camp prisoners of war completed 105,000 man-days of labor, and Camp Algona re-

38. Kossuth County Extension Office, Annual Narrative Reports, 1945, 6; Fort Dodge Messenger, 7/21/1945; Algona Upper Des Moines, 10/25/1945.

39. "Branch Camps: Operations and Activities Map." 
ceived $\$ 504,000$ in compensation. The POWs received a total of $\$ 680,000$ in work coupons for their work. The amount paid to the federal government for their labor was considerable. According to Camp Algona's commanding officer, Lt. Col. Arthur Lobdell, "The value of the labor to the men hiring them was $\$ 3,506,000$, made up of $\$ 2,406,000$ from private employers and $\$ 1,100,000$ from the government." Lobdell estimated that the wholesale value of the food and other products "handled" that otherwise would not have been was $\$ 101,000,000$. Summarizing the success of Camp Algona's labor program, Lobdell claimed, "The work done by these prisoners increases production and helps shorten the war." ${ }^{40}$

Farmers reported their satisfaction with the quality of labor they received from German prisoners, and generally believed that the POWs could turn out a good day's work. According to Lobdell, "Most of the Germans preferred hard, routine manual labor 10 to 12 hours a day. In many places we worked around the clock, two shifts 12 hours each." Prisoners performed best on jobs that required "a minimum of training and skills." One farmer who neglected to instruct the POWs found them pulling soybeans instead of weeds because they did not know the difference. $^{41}$

At first, regulations required fairly tight security. Groups of ten or more prisoners could be divided only if they were kept within a three-mile radius of each other and could be seen by a guard every hour. Farmers had to provide transportation for the guard, enabling him to check on the POWs. Such rules were eventually relaxed as a consistent routine developed among the camp, the prisoners, and the farmer-employers. Dorothy Johnson, who farmed 1,215 acres of land with her husband about three miles northeast of Clarinda, stated that after a relatively short period of time the guard drove his own jeep, checking on the POWs only periodically. Eventually the prisoners who worked on local farms were viewed more as common laborers

40. Lobdell, "Report to Governor Griswold"; Algona Upper Des Moines, 5/3/1945. 41. Lewis and Mewha, History of Prisoner of War Utilization, 128; "A Collection of Memories of the Algona Prisoner of War Camp, 1943-1946," December 1994, vertical file, Algona Public Library; Lobdell, "Report to Governor Griswold"; Des Moines Register, 10/8/1944. 
than as prisoners of war. Dick Norton, whose father employed German POWs on his farm, noted, "My father had hired a group of them to pull the cockleburs in the bean fields. The guard, I discovered when I took some cold soft drinks out to them, was asleep between the bean rows." ${ }^{42}$

Once the "calculated risk" policy was adopted in February 1944, local farmers picked up the German laborers at the camp without guards, and upon arrival the prisoners often drove the farmer's vehicle to specific work locations. Vera Wellhausen, who farmed with her husband about eight miles southwest of Clarinda, commented that the POWs rarely caused problems. If the German prisoners ever complained, they were told that they could always be sent back to camp, a suggestion the prisoners invariably declined. Vera Wellhausen recalled her husband saying, "They were mostly good workers"; he considered one in particular the best laborer he had ever employed. ${ }^{43}$

At times, the relationships that developed between farmers and their captive laborers made it difficult to tell that they were enemies. A Page County farmer remembers an occasion when the German prisoners employed on her farm returned from the fields with reports about all the rabbits and pheasant they had seen. Her husband told the German soldiers to use the old shotgun he kept in his truck the next time they saw game. When the POWs did hunt, the American guard knew it and allowed it. ${ }^{44}$

Like American labor, some German prisoner-of-war workers performed well and some did not, depending upon experience. Mike Loss of Algona, who farmed on a large scale, observed that, although his last group lacked experience, many of them were among his best workers. According to Loss, some of the Germans he hired had no money to buy tobacco when they first came to work for him so he bought them each a corncob pipe and a pouch of tobacco. Walt Bosworth, also of Algona, used some POWs for silo filling and said they were "good workers and had no problems with them." Algonan Jim Fitzpatrick, a

42. Clarinda Herald Journal, 7/3/1944; Des Moines Register, 10/8/1944; Dorothy Johnson, interview with author, Clarinda, Iowa, 3/21/2000; Algona Upper Des Moines, 5/3/1945.

43. Vera Wellhausen, interview with author, Clarinda, Iowa, 3/21/2000.

44. Dorothy Johnson interview. 
camp guard who went out on many work details, commented, "The prisoners were easy to handle and caused us no trouble. They were happy to be here as they were treated well and had good living conditions and good food." ${ }^{45}$

Sometimes farmers came to personally depend on the German POWs who worked for them. Dorothy Johnson recalls an occasion when her husband was forced to leave home and tend to a sick relative. Rather than fear for the welfare of his farm, he said, "Bruno [a German POW who spent the better part of a year working for the Johnsons] will know what to do."

Prisoners played with farmers' children, brought them food and candy, and told stories of their own children back home. On one occasion, when a few Germans were brought to Constance Jergenson's farm to clean up her garden, she was terrified to discover her three-year-old daughter in the midst of them. According to Jergenson, "They were boyish looking young men laughing and chattering in German and seemed delighted to be near a small child. Becky was in glory with the attention. When I ran to get her I realized they were harmless." ${ }^{\prime 7}$

German laborers even ate at the same table as the farmers' families did and became quite fond of American farm cooking — so fond in some cases that they began telling the guards which farmers they wished to work for. Gerald Haas, 12 years old when his parents employed POWs near Algona, recalled, "Farm labor was short during this period. My family hired some prisoners to pull and cut weeds on our land. They had a guard with them, but mostly he sat on the end of the field waiting for them to finish the job. My mom always cooked and fed them their noon meal and as a result they worked very well for us." ${ }^{48}$ On the other hand, one Page County farmer lost the right to contract POW

45. "A Collection of Memories of the Algona POW Camp"; Lobdell, "Report to Governor Griswold"; Algona Upper Des Moines, 10/10/1944; Des Moines Register, 10/8/1944.

46. Dorothy Johnson interview.

47. "A Collection of Memories of the Algona POW Camp."

48. Ibid. 
labor after he took two German prisoners to lunch in a restaurant on the square in Clarinda, a violation of camp regulations. ${ }^{49}$

Farmers commonly employed the same German prisoners repeatedly, and some developed lasting relationships with them. Jean Balgeman Shey remarked, "Five prisoners worked for my father during the summer. They enjoyed coming to my parents' farm and to eat my mother's big meals at noon." Balgeman's father became close to two of the Germans, and kept in touch with them after they returned to Germany. When one of the German POWs, Wilhelm Schittges, was repatriated in 1946, Balgeman's father pulled him aside and told him to write whenever he was hungry back in Germany. The Balgemans ended up sending the Schittges ten packages, and years later, when Jean traveled to Germany to visit the Schittges in 1988, Wilhelm told her that the packages "saved their lives."

In September 1945 a reporter for the Algona Upper Des Moines interviewed a camp guard who spoke about the POWs' opinions of America. He commented, "One [prisoner], who could speak English fluently, still can't believe there can be so rich and wonderful a country as America. This former Nazi is trying his best to stay here, and says he never wants to return to the Reich." Lieutenant J. Beorlage, commander of the Toledo branch camp, noted, "German POWs have little desire to escape and lend themselves well to discipline." ${ }^{51}$ The development of positive relationships contributed to the success of the labor program.

Not all employers readily accepted the German prisoners, however. A few Iowans were either not happy with the quality of labor or could not see beyond one glaring fact: these men were the enemy. Herman Strathe, of Hubbard in Hardin County, employed 20 Germans to detassel seed corn. After using them for only two days, he cancelled the contract because he said the men were not thorough enough. Wayland Hopley, president of the Iowa Beef Producers Association, contacted the War Department with his concerns. Hopley had recently attempted to use

49. Corinne and Wilbur Goecker, interview with author, 3/21/2000; Clarinda Herald Journal, 4/30/1945.

50. Ibid.

51. Algona Upper Des Moines, 9/20/1945; Toledo Chronicle, 8/30/1945. 
ten German POWs from Camp Clarinda on his Atlantic farm. He found the prisoners "surly, fostering their Nazi philosophy and uncooperative." Hopley, who had just lost his son in the European Theater, sent them back to the camp, even though he needed the help. To him, the attitude of the German POWs meant that they had learned nothing and that American soldiers such as his son had died in vain. ${ }^{52}$

Reactions such as these were uncommon, yet they represent the understandable anti-German sentiment many Americans felt. Those feelings could be fed by servicemen writing from abroad. Lieutenant Ted Chrichilles, an Algona native serving in France, wrote an article for the Algona Upper Des Moines in which he criticized recent reports of German prisoners swimming in Algona's \$30,000 pool. According to Lt. Chrichilles, “To me it doesn't make sense - i.e. a Nazi kills 20 of our boys and then gives up and goes to the United States to be treated like some American fighting man with a few privileges taken away." ${ }^{\prime 23}$

Despite scattered opposition, Major General C. H. Danielson, Commanding General of the Seventh Service Command, deemed the farm labor program at Camp Clarinda a success. POW labor problems, he concluded, were "infinitesimal compared to the amount of work obtained." ${ }^{54}$ The successful labor programs at Camp Clarinda and Camp Algona reflected a national trend in POW employment. David Fiedler, in The Enemy among Us, details the generally positive experience of POWs and ordinary citizens in Missouri. According to Fiedler, "The men who lived in the American camps were humanely treated, and the experience was usually far more pleasant than they expected." This is particularly apparent in the stories of enemy prisoners who received warm welcomes when they returned to Missouri years after their repatriation. One former POW stated upon his return, "Even though we don't have any relatives in the States, we feel very much at home here."

52. Hardin County Extension Office, Annual Narrative Reports, 1945, 6-8; Clarinda Herald Journal, 10/19/1944; Shenandoah Evening Sentinel, 9/29/1944.

53. Algona Upper Des Moines, 8/15/1944.

54. Shenandoah Evening Sentinel, 9/29/1944; Clarinda Herald Journal, 10/19/1944.

55. David Fiedler, The Enemy among Us: POWs in Missouri during World War II (St. Louis, 2003), 410. 
Through the analysis of vivid primary documents, Michael Luick-Thrams depicts the growth and transformation of German soldiers in two German POW newspapers published at Camp Algona. Luick-Thrams offers a captivating look into the daily lives of German POWs, from art and poetry to sports and literature, through the words of the camp newspapers (particularly the 1944 pro-Nazi paper Drahtpost, and then, later, in 1945, the anti-Nazi paper Lagerzeitung) which the American authorities encouraged each camp to maintain. According to LuickThrams, enemy prisoners of war "underwent pivotal changes as individuals and as a group - thus fundamentally influencing post-war German values and institutions." ${ }^{56}$

Although Camp Algona's 1945 farm labor program ended with a successful farming season, new information regarding Camp Clarinda's prisoners threatened the success of its farm labor program for the 1945 season. All the hard work that the camp and local community had invested in overcoming the early obstacles to POW employment was jeopardized in January 1945 when news arrived that Japanese soldiers would replace Camp Clarinda's German occupants.

MORE THAN 375,000 Axis prisoners of war lived in captivity in the United States during World War II, but fewer than 6,000 were Japanese. Because of the relatively small number of Japanese soldiers captured alive in the Pacific Theater, only two camps housed Japanese soldiers in the United States: Camp McCoy in Wisconsin and Camp Clarinda in Iowa. Although Camp Clarinda had successfully housed German prisoners, the internment of Japanese POWs posed problems. Early in World War II the Japanese captured approximately 25,000 American soldiers. Within four years, 10,000 had died or been killed. Many of the deaths were attributed to "premeditated, vicious, and inhuman acts" by Japanese soldiers. "Thus, when Japanese prisoners replaced German POWs, who had been generally ac-

56. Michael Luick-Thrams, Camp Papers: Lagerzeitungen, the German POW Newspapers at Camp Algona, Iowa, 1944-1946 (n.p., 2003), i.

57. Krammer, "Japanese Prisoners of War," 67-70; Robert LaForte, Ronald Marello, and Richard Himmel, eds., With Only the Will To Live: Accounts of Americans in Japanese Prison Camps, 1941-1945 (Wilmington, DE, 1994), xxix-79. 
cepted by Iowans, it is no surprise that they were not received warmly.

German prisoners lived in Camp Clarinda from January 1944 until January 1945, when the citizens of Clarinda were notified that Japanese prisoners would replace Camp Clarinda's German occupants. The Japanese POWs arrived in an environment already hostile to those of Japanese descent. In April 1942, according to the Algona Upper Des Moines, several young Japanese American men in Shenandoah - recent graduates of Iowa State College, one of whom had bought a bond "to help his country" - had been attacked and run out of town by a "mob who demanded they be sent to a concentration camp." Community sentiment, stoked by media propaganda regarding the cruelty of Japanese soldiers, forced camp officials to declare that the first 250 Japanese prisoners would not be used for labor outside the camp.

Late in January 1945, less than a week after truckloads of Germans had left Camp Clarinda for Camp Algona, the first Japanese prisoners of war arrived. Most of the Japanese appeared to be between 20 and 45 years old, one-third of whom were "gunzoku," or civilians attached to and under the rules and regulations of the army. Camp commander Lieutenant Colonel George Ball's hatred of the Japanese was obvious when he stated, "They were a sorry lot when they arrived. Some were recovering from wounds. Some were carrying shrapnel. They'd just come from a long duty in the field and they were dirty and wild as animals. We pounded the rudiments of sanitation into their heads, after a little effort, and broke up some of their childlike habits." ${ }^{59}$

Lt. Col. Ball's racist view of the Japanese influenced his administration of the camp. Inside the camp Japanese prisoners were not allowed the same privileges that the Germans had been granted. Each Japanese prisoner received the mandatory

58. Algona Upper Des Moines, 4/14/1942.

59. Des Moines Register, 4/8/1945, 9/23/1945. The Des Moines Register's “Oldtime photo of the day" on July 22, 2010, was a photo of Japanese POWs in their barracks at Camp Clarinda. See www.desmoinesregister.com/article/ 20100722/NEWS13/307220005/1001/NEWS/Old-time-photo-of-the-dayJapanese-POWs-in-Clarinda. 
payment of ten cents per day for work inside the camp, but only 20 to 30 additional cents per day was allowed for certain types of work. Because the Japanese government had signed but not ratified the Geneva Treaty, the U.S. government chose not to pay the Japanese the 80 cents per day that German POWs had received for work outside the camp. Ball commented, "With Japanese, non-signers of the pact, we comply with the rules, alright, and then make them apply to the lower standard of living the Japanese have known."

Ball wasted no time establishing his authority over the Japanese POWs. "If they break any rules," he told a reporter, "they go to the brig. There's no trial. Standard punishment is thirty days in the can, fourteen of them on bread and water; we don't get any repeat offenders." ${ }^{\prime 11}$ Yet, even though the American garrison stationed at Camp Clarinda included veterans of South Pacific combat who harbored contempt for the Japanese prisoners, Ball did not allow any physical punishment even when the Japanese stepped out of line. Officials feared that, despite the Japanese refusal to ratify the Geneva Convention, violation of the treaty could prompt Japanese retaliation against American POWs. Although Ball's policies remained within the bounds of the Geneva Convention, the dispensing of discipline reflected his prejudice and occurred swiftly and sometimes harshly.

One such incident took place early in the Japanese internment. The Japanese arrived on a particularly cold winter day, with plenty of ice and snow on the ground, and they were ordered to go out and shovel. When the Japanese refused to work in the cold weather, Lt. Col. Ball quickly took action. He "sent back word to the effect that no work meant no food. Still they refused. So we got out the military police, clubs and tear gas and marched inside to clean out every ounce of food and every piece of cooking equipment. As we went in they tore out of the barracks like so many monkeys. Some were only half-dressed, but we made them stand out in the cold while we counted them off. They shivered like rats, but they wouldn't work. Next morn-

60. Lewis and Mewha, History of Prisoners of War Utilization, 75n; Des Moines Register, 4/8/1945, 9/23/1945.

61. Des Moines Register, 4/8/1945, 9/23/1945, 12/8/1945. 
ing, after no food at all for twenty-four hours, they sent up word they were ready to go back to work, if we'd feed them first." The Japanese did not receive food until later that night after they had finished their work. ${ }^{62}$

The American garrison encountered few other difficulties with their captives, and camp life for the Japanese came to closely resemble that of the Germans. As of April 19, 1945, approximately 500 Japanese POWs lived in Camp Clarinda along with nearly 200 Germans, members of a specialist detail composed of carpenters, cooks, waiters, and electricians, who were housed in a separate compound. No Japanese officers lived among the prisoners at Camp Clarinda; all Japanese officers resided at Camp McCoy. The Japanese at first expected horrible treatment or death, and they seemed mystified and even happy with their situation. ${ }^{63}$

Even so, deeply ingrained prejudices and preconceptions guided the treatment of the Japanese POWs. According to Lt. Col. Ball, "Because the Jap is a notorious bargainer we use a policy of not giving a damn what he wants. The answer is always no to every request. Then if we think some changes should be made, we make them later, voluntarily." Racist stereotypes would also affect the people of Clarinda; articles littered local newspapers depicting Japanese soldiers as tricky, torturous, and liking to kill their victims slowly. Racist stereotypes and administrative hesitance to employ Japanese POWs seriously threatened the success of the camp's labor program.

The spring 1945 farming season arrived with southwest Iowa in need of even more farm laborers than during the previous season. The Page County Extension Office estimated that 75 percent of local farmers would not be able to find needed help. Extension agent Merril Langfitt remarked, "The only possible way we know for supplying adequate labor for your farming needs is to help make prison labor available for you." ${ }^{\prime 64}$ With all but 200 German POWs sent to Camp Algona and administrators

62. Ibid., 8 April 1945.

63. Clarinda Herald Journal, 12/13/1943, 4/9/1945; Des Moines Register , 4/8/1945.

64. Shenandoah Evening Sentinel, 2/23/1945, 3/7/1945, 5/8/1945. 
reluctant to employ Japanese prisoners outside the compound, it appeared unlikely that those labor needs could be met.

For Page and Fremont counties to have successful farm seasons they needed agricultural workers. Camp Clarinda had a sufficient supply of Japanese prisoners, but farmers demonstrated no interest in using them. The reluctance to employ Japanese prisoners, attributable mainly to misconceptions and racist stereotypes, prevented Japanese labor from being used to its fullest. To overcome this reluctance General Wilhelm D. Styery, commander of the U.S. Army in the Western Pacific, declared, "We must overcome the psychology that you cannot do this or that. I want to see these prisoners work like piss ants! If they do not work, put them on bread and water!" ${ }^{65}$ Lt. Col. Ball took this announcement seriously, so the Japanese POWs at Camp Clarinda were soon contracted for outside work, labor that proved extremely valuable.

Japanese POWs toiled in nurseries and on farms, mostly in groups, as their output lagged if separated. The Japanese POWs who were sent out in work details were always accompanied by an American guard and a "war-dog." In the spring of 1944, in response to general concerns regarding POW labor, the War Department and the War Manpower Commission established a system of incentive pay, in part because of concerns that POW labor was less efficient than free labor in certain situations and because employers did not like to pay on a man-day or manhour basis. As a result, Japanese prisoners were compensated according to the number of "units completed," such as bushels of corn shucked, up to a maximum of $\$ 1.20$ per day. Because the POWs would be paid according to the amount of work done, and not simply for the hours worked, this system rewarded hard workers and punished slow workers. On some occasions Clarinda's camp officials implemented a task system, whereby each POW or detail had a specific amount of work to complete within a certain period of time. In such instances camp officials chose the amount of work to be completed in such a way that, if accomplished, each POW received the 80 cents per day guaranteed by the Geneva Convention.

65. Quoted in Lewis and Mewha, History of Prisoner of War Utilization, 253-54. 
Because negative stereotypes concerning the Japanese prisoners' competence led Clarinda's camp officials to believe that they would be of little value picking corn, a group contracted by a local farmer, Elmer Hodson of Tarkio Township, set out to work on the task system with output expected to be less than that of German labor. ${ }^{66}$ On most occasions, German prisoners acted as foremen on Japanese work patrols, but on March 29, 1945, a Japanese leader with little or no experience picking corn took charge of the group employed on Hodson's farm. The Japanese laborers worked at a rapid pace that the American guards assumed would quickly wear out the prisoners. After the eight-hour day had ended, however, the POWs were still going strong. A dozen Japanese POWs shucked 600-700 bushels the first day, averaging 52-53 bushels per man. According to Lt. Col. Ball, referring to the work done on the Hodson farm, "The first time we used the task rate we took a dozen of these monkeys over to a farmer to help him shuck corn. We had it figured out they could get no more than fifty or sixty cents of corn husked in their eight hours. But, can you imagine it, the men averaged between fifty-two and fifty-three bushels of corn that day. They finished up the day with more than a dollar apiece. We had to make some changes after that.." ${ }^{67}$

Following the work at the Hodson farm, in the fall of 1945, 40 Japanese prisoners were sent to a farm in Ringgold County to pick corn. On that occasion, the Japanese received 10 cents per bushel, so they could not earn as much for a day's work. During the summer detasseling season, the Berry Seed Company in Clarinda employed 1,091 man-days of Japanese labor. Upon discovering that many Japanese soldiers had been former rice farmers, Lt. Col. Ball remarked, "They're good at anything to do with agriculture. They're built so close to the ground they can get down easier." ${ }^{\prime 68}$

66. Ibid., 120-21; Clarinda Herald Journal, 3/29/1945, 4/9/1945, 5/7/1945.

67. Clarinda Herald Journal, 3/29/1945; Des Moines Register, 4/8/1945 (Ball quote). Although the news article makes no mention of it, given the date of this event, the corn must have been left standing over the winter.

68. Page County Extension Office, Annual Narrative Reports, 1945, 9; Des Moines Register, 9/23/1945 (quote); Lewis and Mewha, History of Prisoner of War Utilization, 148-49. 
Having developed a reputation as experts in horticulture, the Japanese were soon contracted to help ease a labor shortage in Shenandoah's busy nurseries. Early in March 1945 one unit of 25 Japanese prisoners worked in the Shenandoah nurseries, assigned to apple tree slip planting. Tying burlap around their knees, they quickly went to work. The nursery operators reported that the Japanese prisoners did more and better work than the former German prisoners. Nursery operators, "well pleased" with the "good job" performed by the Japanese, employed 9,609 man-days of Japanese labor from May to August 1945 after employing 6,750 man-days of German labor the previous year. ${ }^{69}$ Successful employment of Japanese prisoners allowed nursery operators to meet consumer demand and helped to encourage the employment of Japanese POWs in other work outside the camp.

GERMAN AND JAPANESE POWs were employed in Page County for 24,623 man-days through the labor office in 1945. Figuring an average of eight hours per day at 50 cents per hour, the total amount paid by employers for POW labor from May to August 1945 was $\$ 98,492 .^{70}$

Fremont County benefited from German and Japanese POW labor as well. During the 1945 season, the Page County Farm Labor office placed 609 workers with 184 farmers, while Fremont County placed 7,407 workers with 320 farmers, for a total cost of $\$ 70,184 .^{71}$ Between March 22 and November 30, 1945, 121,667 man-hours of POW labor were used in Fremont County to harvest peas, put up hay, cut weeds out of corn, haul manure, feed cattle, build fence, and cut 199,767 pounds of asparagus. Harley Walker commented that the "amount of POW help would be equivalent to every farmer in Fremont County

69. Clarinda Herald Journal, 4/9/1945; Des Moines Register, 4/8/1945; Page County Extension Office, Annual Narrative Reports, 1945, 8.

70. Page County Extension Office, Annual Narrative Reports, 1945, 8-9.

71. Fremont County Extension Office, Annual Narrative Reports, 1945, 2-13. That a larger number of workers were placed in Fremont County but cost less may be explained by the facts that prisoners placed on more than one occasion were counted multiple times and that 90 percent of those employed in Fremont County labored as short-term help in harvesting truck crops. 
using one POW for a period of about ten days." Branch camps had made POW labor more accessible, increasing the number of farmers able to use it. The Herald Journal reported that in Page and Fremont counties "prisoner labor was a lifesaver for farmers this past season. Many farms would not have been run without their help." 72

The end of the war in Europe in May 1945, followed by victory in the Pacific in August, necessitated the process of prisoner repatriation. In August 1945 local newspapers announced that the Japanese POWs were being shipped to the San Joachin Valley in California to help raise vegetables. The Japanese lived in holding camps in California while awaiting their shipment home. By October 1945, Camp Clarinda lost its remaining German POW population. It finally closed on December 1, 1945 . $^{73}$ Lt. Col. Ball left Clarinda to command a camp near Atlanta, Nebraska, and the War Department declared Camp Clarinda surplus, auctioning it off piece by piece. On August 9, 1945, the last of the local soldiers returned home from POW camps in Europe. ${ }^{74}$

Lt. Col. Lobdell was confident that the 10,000 POWs who passed through Algona and its branch camps left Algona in better physical condition than when they arrived. Mentally, only the hard-core Nazis, making up less than 10 percent of the POW population, remained unchanged. Lobdell believed that many of the Germans returned home with the ability to actively participate in the creation of a democratic government. ${ }^{75}$

Eventually, in late 1945, Algona's branch camps began to close, the last being Onawa in November. Camp Algona's German prisoners began leaving in early October, when nearly 1,000 prisoners traveled to Greeley, Colorado, to fill labor needs in the beet fields. In November an additional 2,000 German POWs left Algona headed for the East Coast, from where they would then be sent to France. Finally, on January 22, 1946, 600 more POWs left for Fort Cook, Nebraska, where they were pre-

72. Ibid.; Clarinda Herald Journal, 9/3/1945.

73. Clarinda Herald Journal, 8/16/1945, 10/4/1945; Shenandoah Evening Sentinel, 5/9/1945.

74. Clarinda Herald Journal, 8/9/1945, 10/4/1945, 10/18/1945, 10/22/1945.

75. Lobdell, "Report to Governor Griswold." 
pared for shipment to Europe. One hundred prisoners remained at the camp until its official closing in February 1946, nine months after the war in Europe had ended. Camp Algona was then declared surplus and most was sold off piecemeal. According to historian George Lobdell, nephew of Lt. Col. Arthur Lobdell, "As he drove south out of town, the Colonel could quietly reflect on a job well done during his quite different career as a prisoner of war camp commander." ${ }^{76}$

One German POW at Camp Algona later recalled that as the POWs were driven out of the camp, "the cars stopped on the way out of the small town. People waved their hands. There was standing the farmer, where I have worked. He was standing motionless. Then he [took] off his great hat and hold it in front of his left breast. Many years later I realized [what an] honor this man did to us. God bless the good man." 77 A final statement prepared by the German POWs in Algona reflecting their views on the end of the war read as follows:

We Germans may be glad for two reasons, first the frightful massacre of the last decade has come to an end and the world is moving again. ... Second, the United States will get a fabulous prosperity in the next few years and therefore, will be able to economically support the destroyed Europe. ... Germany has lost the war, but it had to lose it to clear the way to closed resources of the German spirit and German inwardness. If this will give the German people a respect of others' rights we shall be able to establish a German kind of democracy, but the way there is stony and long. ${ }^{78}$

By 1945, Iowans had realized that the economic value of the POWs overcame any real objection to them. In Algona alone, the camp spent an estimated $\$ 4,000$ per month on mess-hall supplies, most of which were purchased locally. Employment of POW labor in nursery and farm work added to their economic value. Edward J. Pluth, in his analysis of the significance of the POW labor program in Minnesota, asserted, "It was not the in-

76. Algona Upper Des Moines, 10/4/1945, 11/22/1945, 1/22/1946; George H. Lobdell, The Golden Rule Challenge: Command of World War II German POW Camps in the Upper Mid-West (Seattle, WA, 2004), 315.

77. Joseph Goetz to Mrs. Ankeny, 3/15/1981, in Palimpsest production files, March/April 1984, State Historical Society of Iowa, Iowa City.

78. Quoted in Lobdell, "Report to Governor Griswold." 
tent of the program that employers profit by using prisoners rather than other labor. But in the absence of other workers, the prisoners helped prevent economically damaging timber and crop losses." The evidence indicates that this was certainly true in Iowa. According to Seth Paltzer, "The economic contribution of the prisoners was substantial. ... At war's end, Lieutenant Colonel Lobdell released a statement that totaled the prisoners' economic contributions at $\$ 3,506,000$ (equivalent to $\$ 54.14$ million today)." ${ }^{79}$

Prisoner-of-war labor may not have always been economically profitable, nor was it always as efficient as civilian labor. Iowa farmers were required to provide transportation in a time when gasoline was rationed, and sometimes the POWs proved less efficient than civilian labor on tasks, such as detasseling corn, that required training. Nevertheless, POW labor prevented crop loss and helped farmers meet increased production demands made by the War Food Administration. Despite sporadic use in corn detasseling, the Page County Emergency Farm Labor Office stated that POWs detasseling five acres produced 50,000 bushels of corn. Page County Extension agent Merril Langfitt, assessing the success of the POW labor program, commented that the prisoner of war "assistance and cooperation greatly assisted in solving the major labor problems in the county."

In time, Iowa communities accepted the camps and their role in waging the war. Not everyone approved of the camps or developed a personal relationship with their inhabitants. When news spread that a camp would come to Algona, many doubted that it would be an asset to the community. Most of the community's inhabitants, however, eventually realized that the camp's existence was necessary for the war effort. Citizens of Algona were pleased to see that these "victims" of a "Hitlerized youth" were going to indirectly aid in the American war effort. Jean Leaneagh Fausnaugh of Algona expressed a typical and crucial observation when she explained, "I remember watching

79. Pluth, "Prisoner of War Employment in Minnesota," 301-2; Seth Paltzer, "Camp Algona: A German Prisoner of War Facility in the American Midwest," On Point: Journal of Army History 16 (Summer 2010), 34-41.

80. Clarinda Herald Journal, 7/6/1944; Page County Extension Office, Annual Narrative Reports, 1944, 8; Des Moines Register, 11/10/1945. 
the long train arrive, and looking hard at the windows, looking for a monster. I looked right in the eyes of one of them - and to my surprise the POW looked like everyone else - one of us." ${ }^{81}$

Local farmers sent care packages to their German laborers well after they had been repatriated. One farmer sent a loan of $\$ 500$ to a former German POW who had worked on his farm, no questions asked. The farmer eventually received repayment. Some local farmers even received visits from their old laborers years later, and naturally the Germans stayed in their homes. Remembering the German prisoners who worked on her farm, Dorothy Johnson said, "We really got acquainted with them. If my son was over there, I hoped someone would treat him as well. When the Germans left they drove them around the square, we all waved and some of us cried." ${ }^{82}$

The Japanese at Camp Clarinda, in spite of feeling the brunt of racism, were treated according to the Geneva Convention and also helped the surrounding community meet war production goals. The greatest effect captivity had on the Japanese POWs, according to Arnold Krammer, was their exposure to democracy which, no doubt, affected some of them for the rest of their lives. $^{83}$

From the construction of the camps in 1943 to their closing in 1946, camp officials carried out a conscious and determined effort to engineer a positive relationship between the camps and the local communities. Establishing POW camps in Iowa proved beneficial both for the government and for Iowans. Iowa was a safe and secure environment for POW internment, and the camps became assets to the local communities. Demonstrating their willingness to employ enemy workers, Iowans helped the camps operate successful labor programs that ensured that crops did not rot in the fields, that farmers met wartime production goals, and that American soldiers were fed overseas. An unsuccessful labor program would have been financially devastating for local nurseries, canneries, and hemp plants. Instead, the camps

81. Algona Upper Des Moines, 10/14/1943, 6/6/1944, 6/27/1944; “A Collection of Memories of the Algona POW Camp."

82. "A Collection of Memories of the Algona POW Camp"; Dorothy Johnson interview.

83. Krammer, "Japanese POWs in America," 89-90. 
brought substantial military payrolls that stimulated the local economies and provided essential workers.

Confronted with the enemy, Iowans realized that the prisoners were indeed human. Accepting the POWs fulfilled Iowans' sense of duty and helped the United States win the war. Iowans also hoped that their fair treatment of enemy POWs would encourage similar treatment of their loved ones in enemy POW camps overseas. Interactions with some of these enemies not only helped to solve the critical shortage of labor, but also in a relatively brief period sometimes developed into relationships that would last a lifetime. 